\title{
PENGGUNAAN MEDIA PEMBELAJARAN EDMODO DENGAN DESAIN PEMBELAJARAN ASSURE GUNA MEMPERBAIKI KINERJA GURU PADA MATA PELAJARAN KONSTRUKSI BANGUNAN SISWA KELAS X TEKNIK KONSTRUKSI BATU DAN BETON DI SMK NEGERI 2 SURAKARTA TAHUN PELAJARAN 2016/2017
}

Oleh

\author{
1. Bayu Wicaksono \\ 2. Dr. H. Roemintoyo, S.T, M.Pd \\ Abdul Haris Setiawan, S.Pd., M.Pd \\ Email: bayu.moster62@gmail.com
}

\begin{abstract}
The current educational process shows that many students who are less active during the learning process. Learning process is focused on the teachers only which affects the students' lack of understanding of the lesson. This study aims to determine the application of edmodo media with ASSURE learning design on teacher performance and student learning outcomes. This research is a classroom action research conducted in class X TKBB SMK N 2 Surakarta, amounting to 31 students. This research was conducted in two cycles. Each cycle consists of the planning, implementation, observation, and refletion phases. The research instrument used consisted of teacher performance appraisal, student performance appraisal by teacher, cognitive, psychomotor, and affective assessment. The validity of the data using triangulation and analyze the data using descriptive quantitative analyze model by using descriptive statistics.The results showed that at the time of pre-cycle of teacher performance included in category $C$ with value 66,67, cycle I entered in category B with value of 75,00 and cycle II entered in category $B$ with value 83,33. Its mean, Edmodo media with ASSURE learning design can improve teacher performance. In each cycle, as well as the increase in student learning outcomes, this means increased teacher performance also has an impact on increasing student learning outcomes
\end{abstract}

Keywords: ASSURE, edmodo, teacher performance, learning outcomes

1.Mahasiswa Program Studi Pendidikan Teknik Bangunan FKIP Universitas Sebelas Maret 2.Pengajar Program Studi Pendidikan Teknik Bangunan FKIP Universitas Sebelas Maret 


\section{PENDAHULUAN}

Undang-Undang

Sistem

Pendidikan Nasional No 20 Tahun

2003 berbunyi:

Pendidikan nasional berfungsi mengembangkan kemampuan dan membentuk watak serta peradaban bangsa yang bermartabat dalam rangka mencerdaskan kehidupan bangsa, bertujuan untuk berkembangnya potensi peserta didik agar menjadi manusia yang beriman dan bertaqwa kepada Tuhan Yang Maha Esa, berakhlak mulia, sehat, berilmu, cakap kreatif, mandiri dan menjadi warga negara yang berdemokrasi serta bertanggung jawab.

Kenyataan dalam pendidikan sekarang ini masih banyak siswa yang kurang aktif selama proses pembelajaran. Hal ini menyebabkan proses pembelajaran yang berorienasi pada guru semata. Pembelajaran yang berorentsi pada guru semata menyebabkan kurangnya pemahaman siswa akan materi yang diajarkan, sehingga siswa juga mengalami kesulitan dalam mengembangkan dirinya berkaitan dengan mata pelajaran yang diajarkan

Berdasarkan data yang diperoleh dari wawancara pada saat program pengalaman lapangan bulan September-November 2016 dengan bapak Purwana Budi Santosa selaku guru mata pelajaran Konstruksi bangunan kelas $\mathrm{X}$ TKBB di SMK Negeri 2 Surakarta menunjukkan bahwa hasil belajar siswa pada saat pelajaran konstruksi bangunan sangat rendah yaitu sekitar 29\% dari jumlah siswa. Hal ini disebabkan karena kurangnya kemampuan guru dalam memilih strategi pembelajaran dan memanfaatkan media pembelajaran.

Berdasarkan permasalahan diatas, maka perlu dilakukannnya tindakan terkait inovasi dalam pembelajaran sehingga dapat menumbuhkan keaktifan siswa pada saat pelajaran adalah dengan menggunakan metode dan media pembelajaran yang tepat agar tercipta suasana kelas yang aktif dan kondusif.

Melalui penerapan desain pembelajaran yang tepat, seorang guru dapat mengidentifikasi masalah dan menetapkan masalah, menganalisis dan merumuskan masalah, serta selanjutnya mengadakan tindakan perbaikan terhadap masalah-masalah yang ada saat pembelajaran, sehingga guru dapat menemukan solusi 
permasalahan dengan menerapkan tahap-tahap penelitian yang dilakukan di saat siklus pelajaran. Setelah hal itu dilakukakan, guru dapat menyimpulkan dan mengevaluasi hasil dari perbaikan yang telah dilakukan, sehingga masalah dalam kelas dapat teratasi dengan tuntas.

Media pembelajaran Edmodo dipilih untuk memperbaiki kinerja guru dan hasil belajar siswa karena media tersebut mempunyai konsep yang cocok untuk pembelajaran berbasis jejaring sosial yang aman dan gratis dalam memudahkan guru untuk membuat dan mengelola kelas virtual sehingga siswa dapat terhubung dengan teman sekelas dan guru kapan saja dan dimana saja. (Balasubramanian \& Jayakumar, 2014: 416)

Edmodo adalah sebuah media pembelajaran sosial untuk guru/dosen, siswa /mahasiswa maupun untuk orang tua/wali yang dikembangkan pada akhir 2008 oleh Nic Borg dan Jeff O"Haa yang menyatakan kebutuhan untuk berkembang di lingkungan sekolah/kampus untuk mencerminkan sebuah alat/aplikasi yang dapat menutup kesenjangan antara bagaimana siswa/mahasiswa menjalani kehidupan mereka dan bagaimana mereka belajar di sekolahan/kampus, untuk itulah maka Edmodo ada.

Berdasarkan yang telah dijelaskan dalam latar belakang masalah diatas, maka dapat dirumuskan masalah penelitian ini: 1) Bagaimana penerapan media pembelajaan Edmodo dengan desain pembelajaran ASSURE guna memperbaiki kinerja guru dan meningkatkan hasil belajar siswa pada mata pelajaran Kostruksi Bangunan siswa kelas $\mathrm{X}$ program keahlian Teknik Konstruksi Bangunan di SMK N 2 Surakarta tahun pelajaran 2016/2017? 2)Apakah media pembelajaan Edmodo dengan desain pembelajaran ASSURE dapat memperbaiki kinerja guru pada mata pelajaran Kostruksi Bangunan siswa kelas $\mathrm{X}$ program keahlian Teknik Konstruksi Bangunan di SMK N 2Surakarta tahun pelajaran 2016/2017? 3)Apakah media pembelajaan Edmodo dengan desain pembelajaran ASSURE dapat meningkatkan hasil 
belajar siswa pada mata pelajaran Konstruksi Bangunan siswa kelas X program keahlian Teknik Konstruksi Bangunan di SMK N 2 Surakarta tahun pelajaran 2016/2017?

Berdasarkan paparan di atas maka tujuan penelitian tindakan kelas ini adalah sebagai berikut: 1) Mengetahui penerapan media pembelajaan Edmodo dengan desain pembelajaran ASSURE dapat memperbaiki kinerja guru dan meningkatkan hasil belajar siswa pada mata pelajaran Kostruksi Bangunan siswa kelas $\mathrm{X}$ program keahlian Teknik Konstruksi Bangunan di SMK N 2 Surakarta tahun pelajaran 2016/2017. 2) Memperbaiki kinerja guru pada mata pelajaran Kostruksi Bangunan menggunakan media pembelajaran Edmodo dengan desain pembelajaran ASSURE siswa kelas $\mathrm{X}$ program keahlian Teknik Konstruksi Bangunan di SMK N 2 Surakarta tahun pelajaran 2016/2017. 3) Meningkatkan hasil belajar siswa menggunakan media pembelajaran Edmodo dengan desain pembelajaran ASSURE pada mata pelajaran Kostruksi Bangunan siswa kelas $\mathrm{X}$ program keahlian Teknik Konstruksi Bangunan di SMK N 2 Surakarta tahun pelajaran 2016/2017.

\section{Media Pembelajaran}

Asnawir dan Usman (2002:11) menyatakan secara harfiah, kata media berasal dari bahasa latin medium yang memiliki arti "perantara" atau "pengantar". Menurut Asosiasi Teknologi, Kmunikasi, dan Pendidikan (Association for Education and Communication technology/AECT) mendefinisikan bahwa :

$$
\begin{aligned}
& \text { Media sebagai benda yang } \\
& \text { dapat dimanipulasikan, } \\
& \text { dilihat, didengar, dibaca atau } \\
& \text { dibicarakan beserta } \\
& \text { instrument yang dipergunakan } \\
& \text { dengan baik dalam kegiatan } \\
& \text { belajar mengajar, dapat } \\
& \text { mempengaruhi efektifitas } \\
& \text { program instruksional. } \\
& \text { Sedangkan pembelajaran atau }
\end{aligned}
$$
ungkapan yang lebih dikenal sebelumnya "pengajaran" adalah upaya untuk membelajarkan siswa. Oemar Hamalik menuturkan bahwa pembelajaran adalah suatu kombinasi yang tersusun meliputi unsur-unsur manusiawi, material, fasilitas, perlengkapan dan prosedur yang saling mempengaruhi tercapainya 
tujuan pembelajaran. Sedangkan menurut Kamus Besar Bahasa Indonesia pembelajaran adalah proses, cara, perbuatan yang menjadikan orang atau makhluk hidup belajar .

Jika dilihat dari pendapat di atas media pembelajaran adalah suatu alat yang digunakan sebagai perantara komunikasi dalam rangka lebih mengefektifkan komunikasi dan interaksi antara guru dan siswa dalam proses pendidikan pengajaran di sekolah.

\section{Edmodo}

Menurut Balasubramanian \& Jayakumar (2014: 416), Edmodo adalah pembelajaran berbasis jejaring sosial yang aman dan gratis dalam memudahkan guru untuk membuat dan mengelola kelas virtual sehingga siswa dapat terhubung dengan teman sekelas dan guru kapan saja dan dimana saja. Gatot dalam (Singgih \& Meini, 2013) mendefinisikan Edmodo sebagai aplikasi edukasi dengan platform media sosial dan cloud menyerupai facebook yang dapat digunakan dalam pembelajaran. Sejalan dengan pandangan Gatot,
Sudibjo (2013: 188) mengemukakan bahwa Edmodo diciptakan menggunakan konsep yang mirip dengan facebook, dimana tujuan pembuatannya adalah khusus untuk bidang pendidikan yang dapat mendukung proses pembelajaran secara online.

Berdasarkan uraian di atas, dapat disimpulkan bahwa Edmodo merupakan media pembelajaran berbasis jejaring sosial menyerupai facebook yang digunakan guru untuk berintraksi dengan siswa dalam proses pembelajaran yang bersifat online dan digunakan kapan dan dimana saja.

\section{Desain Pembelajaran}

Beberapa pengertian desain pembelajaran menurut para ahli dapat diuraikan sebagai berikut:

$$
\text { Hamdani (2011: 71) }
$$

menyatakan bahwa "Desain pembelajaran adalah disiplin ilmu yang berhubungan dengan pemahaman dan perbaikan satu aspek dalam pendidikan, yaitu proses pembelajaran".

Selanjutnya Baris Sezer et.al (2013) dalam International Journal 
on New Trends in Education and Their Implications: "Instructional design (ID) is a systematic process that is employed to develop education and training programs in a consistent and reliable fashion". Pernyataan ini dapat diartikan bahwa desain pembelajaran adalah proses sistematis yang digunakan untuk mengembangkan program-program pendidikan dan pelatihan secara konsisten dan dapat diandalkan.

Kemudian Benny Pribadi (2011: 24) menyatakan bahwa “desain pembelajaran adalah upaya untuk membuat aktivitas pembelajaran menjadi terstruktur dan sistematis".

Berdasarkan pendapat para ahli di atas, dapat disimpulkan bahwa desain pembelajaran adalah proses yang terstruktur dan sistematis guna menciptakan sarana yang optimal untuk mencapai tujuan pembelajaran.

\section{Desain ASSURE}

Menurut Afandi dan Badarudin, (2011:22) desain ASSURE adalah salah satu petunjuk dan perencanaan yang bisa membantu untuk bagaimana cara merencanakan, mengidentifikasi, menentukan tujuan, memilih metode dan bahan, serta evaluasi.

Berikut ini adalah langkahlangkah dalam desain pembelajaran ASSURE menurut Pribadi (2011:113-116):

1. Analyze Learners (Analisis Pembelajar)

2. State Standards And Objectives (Menentukan Kompetensi Atau Tujuan Pembelajaran Yang Diharapkan Tercapai)

3. Select Strategies, Technology, Media, And Materials(Memilih Metode, Media Dan Bahan Ajar)

4. Utilize Technology, Media, And Materials (Menggunakan Metode, Media Dan Bahan Ajar)

5. Require Learner Participation (Mengembangkan Partisipasi Peserta Didik)

6. Evaluate And Revise (Mengevaluasi Dan Merevisi)

\section{Kinerja Guru}

Lindsay and Patrick dalam (Hasan, 2004:17) lebih menekankan kepada perilaku orang yang melaksanakan pekerjaan tersebut, selanjutnya ia menyatakan," kinerja 
guru adalah perilaku yang berhubungan dengan penyelesaian pekerjaan yang di harapkan, spesifik atau bersifat normal oleh setiap anggota organisasi”. Mitriani dalam (Hasan 2004: 17) menyatakan, "kinerja adalah perangkat proses untuk menciptakan pemahaman bersama mengenai apa yang harus di capai, bagaimana hal itu harus dicapai serta bagaimana mengatur orang dengan cara meningkatkan kemungkinan tercapainya tujuan".

Beberapa pendapat di atas dapat di jelaskan bahwa kinerja tidak saja dilihat dari hasil suatu pekerjaan tetapi juga dapat dilihat dari perilaku seseorang dalam melaksanakan pekerjaannya.

\section{Hasil Belajar}

Hasil belajar merupakan perubahan perilaku yang diperoleh pembelajar setelah mengalami aktivitas belajar. Perolehan aspekaspek perubahan tersebut tergantung dari apa yang dipelajar oleh pembelajar. Oleh karena itu jika pembelajar mempelajari pengetahuan tentang konsep, maka perubahan perilaku yang sesuai adalah penguasaan akan konsep.

Menurut W.S. Winkel (2009: 280-285) : Tujuan pendidikan yang hendak dicapai dapat diklasifikasikan menjadi tiga bidang, yaitu: Ranah Kognitif, Afektif, dan Psikomotorik

\section{METODE PENELITIAN}

Tempat penelitian tindakan kelas pada penelitian ini dilaksanakan di SMK Negeri 2 Surakarta JL. Adisucipto

Manahan Surakarta 57139. Telepon, 0271 714901. Waktu pelaksanaan penelitian dilakukan mulai bulan Januari 2017 sampai bulan Juli 2017. Subjek penelitian ini adalah guru dan siswa kelas X TKBB SMK Negeri 2 Surakarta tahun ajaran 2016/2017.

Teknik pengumpulan data yang digunakan yaitu dengan wawancara yang dilakukan sebelum dan sesudah penelitian, data yang diambil dari dokumentasi video dan foto kegiatan pembelajaran mata pelajaran teknik konstruksi batu dan beton sebelum dan sesudah dilaksanakan tindakan, daftar hasil tes dan tes yang dilakukan. 
Teknik uji validitas data yang dipakai dalam penelitian ini adalah triangulasi dan review informan terkunci. Teknik triangulasi yang digunakan dalam penelitian ini adalah triangulasi sumber data dan triangulasi metode pengumpulan data. Review informan terkunci sebagai sumber dalam penelitian ini adalah anggota peneliti.

Teknik analisis data yang digunakan penelitian ini adalah teknik analisis model interaktif yang diungkapkan oleh Sugiyono (2006). Model analisis ini terdiri atas empat tahap pokok yaitu pengumpulan data, reduksi data, sajian data, dan kesimpulan.

Indikator kerja yang digunakan untuk kinerja guru mendapat nilai 75 untuk penampilan guru dan predikat B untuk penilaian siswa terhadap guru, sedangkan untuk ranah kognitif, afektif, dan psikomotorik sebanyak $80 \%$ siswa memperoleh nilai 76,00.

Prosedur dalam penelitian tindakan kelas ini ditambah dengan desain ASSURE sehingga menjadi perencanaan (Analyze Learners, State Standards And Objectives Select
Strategies, Technology, Media, And Materials,Utilize Technology, Media, And Materials), pelaksanaan (Require Learner Participation), pengamatan, refleksi (Evaluate And Revise).

\section{HASIL TINDAKAN DAN PEMBAHASAN}

Hasil tindakan antar siklus ini dimulai dari sebelum diberi tindakan berupa penerapan media Edmodo dengan desain ASSURE (pra siklus) sampai dengan setelah di beri tindakan berupa penerapan media Edmodo dengan desain ASSURE (siklus I, siklus II).

Dari hasil penelitian dapat diliha bahwa penerapan media Edmodo dengan desain ASSURE kinerja guru dan hasil belajar siswa mengalami perbaikan setiap siklusnya. Peningkatan setiap indikator dalam penelitian dapat disajikan sebagai berikut:

Tabel 1. Pencapaian Kinerja Guru dalam Pembelajaran

\begin{tabular}{cc}
\hline \multirow{2}{*}{ Siklus } & Target Nilai \\
\cline { 2 - 2 } & $\begin{array}{c}\text { Penampilan Guru } \\
\text { Mengajar }\end{array}$ \\
\hline Pra Siklus & 66,67 \\
\hline Siklus I & 75,00 \\
\hline Siklus II & 83,33 \\
\hline
\end{tabular}


Tabel 2. Pencapaian Penilaian Kinerja Guru oleh Siswa

\begin{tabular}{lc}
\hline \multirow{1}{*}{ Siklus } & Kinerja Guru \\
\cline { 2 - 2 } & Penilaan Siswa \\
\hline Pra Siklus & 2.48 (predikat C) \\
\hline Siklus I & 3.07 (predikat B) \\
\hline Siklus II & 3.12 (predikat B) \\
\hline
\end{tabular}

Tabel 4. Perandingan Hasil Belajar Siswa

\begin{tabular}{lccc}
\hline Kegiatan & Kognitif & $\begin{array}{c}\text { Psikomo } \\
\text { torik }\end{array}$ & Afektif \\
\hline Pra Siklus & $29,03 \%$ & $51,61 \%$ & $41,94 \%$ \\
\hline Siklus I & $61,29 \%$ & $87,10 \%$ & $61,29 \%$ \\
\hline Siklus II & $83,87 \%$ & $90,32 \%$ & $80,65 \%$ \\
\hline
\end{tabular}

Kondisi pra siklus terlihat proses pembelajaran masih rendah karena kurangnya upaya guru untuk menciptakan suasana kelas yang menarik dan menyenangkan. Kurangnya upaya guru tersebut membuat penilaian kinerjanya menjadi rendah dan tingkat kepuasan atau penilaian kinerja guru oleh siswa pun rendah. Hal tersebut terlihat dari hasil observasi penilaian kinerja guru dalam penampilan mengajar mendapatkan nilai 66,67 dan penilaian kepuasan siswa akan kinerja guru mendapat nilai 2,48 atau predikat C. hasil tersebut masih berada dibawah target pencapaian indikator penelii yaitu 75 untuk penilaian kinerja guru dan 2,51 atau predikat B untuk penilaian kepuasan siswa akan kinerja guru. Kurangnya kinerja guru berdampak pada hasil belajar siswa yaitu ranah kognitif siswa yang mencapai target ketuntasan hanya 29,03\%, ranah psikomotorik siswa yang mencapai target ketuntasan hanya $51,61 \%$, dan ranah afektif siswa yang mencapai target ketuntasan hanya $41,94 \%$. Persentase tersebut masih dibawah target ketuntasan yang ditetapkan yaitu $80 \%$ siswa mendapat nilai diatas KKM yang sebesar 76. Maka dari itu peneliti melakukan koordinasi dengan guru pengampu untuk memperbaiki kinerja guru dan hasil belajar siswa didalam kelas. Dari hasil pengamatan pada pra siklus guru dan peneliti merancang apa yang perlu disiapkan untuk penelitian pada siklus I dengan menggunakan desain pembelajaran ASSURE.

Desain pembelajaran ASSURE ini digunakan sebagai pedoman untuk mendesain proses pembelajaran yang optimal. Langkah-langkah desain pembelajaran ini memudahkan peneliti dan guru untuk berkoordinasi 
dalam upaya memperbaiki kinerja guru dan hasil belajar siswa. Dari hasil analisis karakteristik siswa serta penetapan tujuan pembelajaran kemudian didapatkan media yang cocok untuk preses pembelajaran di mata pelajaran Konstruksi Bangunan yaitu media pembelajaran Edmodo yang berbasis pembelajaran $E$ learning yang dimana guru dan siswa akan dipermudah untuk berinteraksi walaupun tidak didalam kelas serta untuk pengumpulan tugas serta ujian dapat dipermudah hanya dengan masuk ke Edmodo. Media Edmodo ini sangat cocok untuk karateristik siswa yang pasif dan pembelajaran yang berfokus ke guru. Kemudian peneliti dibantu oleh guru menyiapakan rencana pelaksanaan pembelajaran untuk siklus I.

Pada siklus I guru menjelaskan materi kemudian siswa di beri tugas untuk membuat rangkuman pembelajran. Hal ini dilakukan agar siswa dapat belajar mandiri dan siswa agar terlihat lebih aktif. Setelah pekerajaan selesai guru menerangkan cara mengirim hasil tugas ke media Edmodo. Hasil pengamatan menunjukan bahwa pada siklus I ini pekerjaan guru dapat dipermudah dengan Edmodo karena guru sudah memasukan atau menyiapkan tugas kelompok dan tugas individu di laman Edmodo sehingga siswa hanya tinggal masuk ke laman Edmodo untuk mengerjakan dan guru dapat lebih mudah memantau hasil pekerjaan siswa tetapi masih terdapat kendala seperti pembelajaran guru masih searah terlihat disaat pencapaian penilaian penampilan guru mendapat nilai 75,00 dan penilaian kinerja oleh siswa mendapat nilai 3,07 atau prdikat B dari hasil kinerja guru tersebut berimbas juga kepada siswa dikarenakan guru masih binggung menerangkan kepada siswa cara kegunaan media Edmodo sehingga ada beberapa siswa yang masih tidak memperhatikan guru saat menerangkan dan menggunakan media Edmodo, disaat pembelajaran masih ada beberapa siswa yang masih belum mencapai nilai ketuntasan minimal, terlihat dari hasil belajar siswa ranah kognitif hanya $61,29 \%$ siswa yang tuntas, ranah psikomotorik $87,10 \%$ siswa yang tuntas, dan ranah afektif hanya 61,29\% yang mencapai ketuntasan. 
Dari kekurangan tersebut, peneliti dan guru dibantu dengan desain pembelajaran ASSURE menganalisi dan mencari solusi dimana didapat adanya penambahan dengan metode diskusi mengatasi kekurangan dan kelemahan dalam pembelajaran Konstruksi Bangunan.

Pada siklus II, materi tetap lanjutan dari siklus I yaitu pekerjaan konstruksi baja. Didalam siklus II ini guru sebelumnya memberikan materi ke siswa dan memberikan tugas yang dikirim ke Edmodo sehingga dapat dibahas pada pertemuan siklus II ini. Pada siklus II ini guru membagi kelompok lagi menjadi 3 bagain dan memberikan tugas masing-masing kelompok tentang sambungan baj, didalam kelompok tersebut siswa harus menjelaskan pengertian sambungan baja dan keunggulan dan kekurangan dari sambungan baja tersebut lalu setiap kelompok diminta membuat soal dan jawaban untuk dilemparkan kekelompok lain, lalu hasil pekerjaan dikirim ke medai Edmodo. Dari hasil pengamatan pada siklus II pekerjan guru dipermudah karena siswa sudah dapat materi dari kiriman guru di laman Edmodo, sehingga saat guru menerangkan siswa tinggal menyimak dan mendengarkan bahkan bertanya tentang materi yang belum di mengerti, sedangkan penyampaian tugas melalui Edmodo juga menghemat waktu karena guru tidak lagi harus menunggu sampai pertemuan yang akan datang baru dibagikan kepada siswa, siswa pun uga dapat mencoba mengerjakan tugas dirumah, dan apbila siswa menemui masalah bisa langsung ditanyakan kepada guru dalam forum diskusi di laman Edmodo jika waktu tidak memungkinkan untuk bertatap muka langsung di kelas. Seiring mulai adanya perbaikan kinerja guru, hasil belajar siswa juga mengalami perbaikan terlihat dari perolehan penampilan guru mendapat nilai 83,33 dan kepuasan siswa akan guru mendapat nilai 3,12 atau predikat B. Hasil belajar siswa dari ranah kognitif, psiomotorik, dan afektif semua mengalami kenaikan dari persentase ketuntasan maupun ratarata kelas terlihat dari ranah kognitif mendapat persentase ketuntasan mncapai $83,87 \%$ ranah psikomotorik 
$90,32 \%$ dan ranah afektif mendapat $80,65 \%$.

Berdasarkan hasil wawancara dengan guru setelah pelaksanaan tindakann siklus I dan siklus II menunjukan bahwa pembelajaran menggunakan media Edmodo dengan desain ASSURE membuat pembelajaran lebih menyenangkan, dengan adanya Edmodo siswa merasa semangat saat pembelajaran dan desain pembelaaran ASSURE sangat membantu guru untuk memilih langkah terbaik untuk memperbaiki proses pembelajaran, tetapi bagi guru yang sudah lanjut usia dengan adanya media Edmodo malah mempersulit kinerja guru dalam pembelajaran dikarenakan harus konek dulu ke internet dan memasukan soal ke laman Edmodo.

Sedangkan hasil wawancara siswa pembelajaran menggunakan media Edmodo lebih menarik dan jadi lebih dapat dipahami tetapi didalam penggnaan Edmodo siswa mendapat kendala yaitu koneksi internet sekolah yang tidak stabil sehingga membuat siswa harus menggunakan paket internet pribadi.

\section{SIMPULAN}

Penerapan media pembelajaran

Edmodo dilaksanakan dengan desain pembelajaran ASSURE berupa Analize Learner, State Standards And Objective, Select Strategies, Technology, Media, And Materials, Utilize Technology, Media, And Materials, Require Learner partisipation dan Evaluate And Revise dengan penambahan metode diskusi dimana siswa dibagi menjadi 3 kelompok besar pada Require Learner Partisipation.

$$
\text { Penggunaan media }
$$

pembelajaran Edmodo dengan desain pembelajaran ASSURE dapat memperbaiki kinerja guru dalam mata pelajaran Konstruksi Bangunan pada kelas X Teknik Konstruksi Batu dan Beton SMK Negeri 2 Surakarta. Hal ini dapat dilihat pada saat pra siklus, kinerja guru berada pada kategori $\mathrm{C}$ dengan nilai 66,67 yang artinya kinerja guru masuk dalam kategori buruk, kemudian dilakukan tindakan sehingga menghasilkan peningkatan nilai kinerja guru menjadi 75,00 dan masuk dalam kategori B pada siklus I kemudian terus meningkat pada siklus II menjadi 83,33 


\begin{abstract}
Membaiknya kinerja guru setelah diterapkannya media pembelajaran Edmodo dengan desain ASSURE berdampak juga terhadap hasil belajar siswa. Berdasarkan hasil analisis data penelitian menunjukkan bahwa pada setiap siklusnya mengalami peningkatan hasil belajar siswa baik ranah kognitif, afektif, maupun ranah psikomotorik.
\end{abstract}

\section{DAFTAR PUSTAKA}

Afandi dan Badarudin. (2011). Perencanaan Pembelajaran. Banung: Alfabeta

Asnawir dan M. Basyiruddin Usman (2002). Media Pembelajaran. Jakarta: Ciputat Pers.

Balasubramanian, Kandappan \& Jaykumar, Leena N. K. (2014). Student Preference Towards The Use Of Edmodo As A Learning Platform To Create Responsible Learning Environment. Prosiding, Asia Euro Conference. Selangor : School of Hospitality, Tourism and Culinary Arts, Taylor's University.

Departemen Pendidikan Nasional, 2003. Undang-Undang Nomor 20 Tahun 2003, Tentang Sistem Pendidikan Nasional, Jakarta: Depdiknas

Hamdani. (2011). Strategi Belajar Mengajar. Bandung: Pustaka Setia.
Hasan, I.(2004), Analisis Dana Penelitian Dengan Statistik, Jakarta: Bumi Aksara.

Pribadi, Benny A (2011). Model Desain Sistem Pembelajaran. Jakarta : Dian Rakyat.

Sudibjo, Ari (2013) Penggunaan Media Pembelajaran Fisika Dengan E-Learning Berbasis Edmodo Blog Education Pada Materi Alat Optik Untuk Meningkatkan Respons Motivasi Dan Hasil Belajar Siswa Di SMP N 4 Surabaya. Jurnal Inovasi Pendidikan Fisika,

Winkel, WS. (2009). Evaluasi Program Pembelajaran. Pustaka Pelajar 